Research article

\title{
CARDIORESPIRATORY AND HEMODYNAMIC EFFECTS OF MEDETOMIDINE OR XYLAZINE WITH ATROPINE AND DIAZEPAM PREMEDICATION FOR TOTAL INTRAVENOUS ANESTHESIA INDUCED AND MAINTAINED WITH PROPOFOL/FENTANYL IN DOGS UNDERGOING SURGERY
}

\author{
LIPTÁK Tomášs ${ }^{*}$, CAPÍK Igor ${ }^{1}$, LEDECKÝ Valent ${ }^{1}$, NAGY Oskar², KURICOVÁ \\ Mária ${ }^{1}$ TÓTHOVÁ Csilla ${ }^{2}$, MAĎARI Aladár ${ }^{1}$, FARBÁKOVÁ Jana ${ }^{1}$, PETROVIČ \\ Vladimír ${ }^{3}$, HORÑÁK Slavomír ${ }^{1}$
}

${ }^{1}$ Small Animals Clinic, University of Veterinary Medicine and Pharmacy, Komenskeho 73, Kosice, Slovak Republic; ${ }^{2}$ Clinic for Ruminants, University of Veterinary Medicine and Pharmacy, Komenskeho 73, Kosice, Slovak Republic; ${ }^{3}$ Department of the environment, veterinary legislation and economy, University of Veterinary Medicine and Pharmacy, Komenskeho 73, Kosice, Slovak Republic

(Received 26 February; Accepted 06 May 2014)

The aim of this study was to compare the effects of different premedication protocols followed by a propofol/fentanyl TIVA on cardio-respiratory and hemodynamic changes in twenty-four dogs randomly divided into two groups (AMD-group: medetomidine, atropine and diazepam; AXD-group: xylazine, atropine and diazepam). Cardiorespiratory variables, acid-base indices, quality of sedation, induction, intubation and recovery were recorded throughout the experiment.

Significant changes were observed for the $\mathrm{pO}_{2}$ level, which was increased in the AMDgroup from $90 \mathrm{~min} .(* \mathrm{P}<0.05)$ to $120 \mathrm{~min} .(* * \mathrm{P}<0.01)$ of anesthesia. This can be explained by a reduction of the administration rate of propofol/fentanyl TIVA and oxygenation initiated due to excessively deep anesthesia detected by an anesthetsiologist, leading to improved ventilation and increased $\mathrm{pO}_{2}$. The $\mathrm{pCO}_{2}(* \mathrm{P}<0.05)$ reached more preferable values during the first $30 \mathrm{~min}$. and $\mathrm{pH}(* * \mathrm{P}<0.01)$ was significantly improved within the first $60 \mathrm{~min}$. in the AXD-group thanks to less depressant effects of xylazine. Within the first $30 \mathrm{~min}$. of anesthesia a significant heart rate difference between the groups was accompanied with significantly higher BP (hypertension) in the AXD-group $\left(10 \mathrm{~min} .{ }^{* * *} \mathrm{P}<0.001,30 \mathrm{~min} .{ }^{* *} \mathrm{P}<0.01\right)$. This points to the possibility of atropine application only in the case of a tendency to bradycardia followed by hypotension.

It can be concluded that xylazine is a better option for the premedication of a propofol/ fentanyl TIVA in dogs undergoing a prolonged surgical intervention, in spite of the fact that lower sedation scores were attained. We have detected significantly less adverse cardio-respiratory and hemodynamic effects of xylazine, and a shorter recovery time when compared to medetomidine.

Key words: intravenous anesthesia, long-term anesthesia, dog, Fentanyl, Propofol

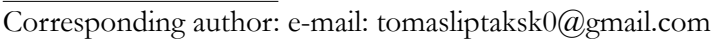




\section{INTRODUCTION}

Surgical interventions in animals requiring general anesthesia are routinely maintained via inhalation of volatile anesthetic agents, however there are some contraindications (such as gastoresophageal reflux or epilepsy) which can limit their usage. For these reasons, a total intravenous anesthesia (TIVA) could provide a suitable alternative to this method, mostly, but not only when short surgical anesthesia is required, because various combinations of drugs at different doses can be administered [1, 2]. The integral part of the perioperative management is also the administration of antibiotics [3]. Different degrees of sophistication of TIVA, from simple continuous to target controlled infusions, are used in veterinary practice. Nevertheless, the general principle of TIVA is to control the infusion rates of drugs, thus allowing the regulation of their concentrations in the blood with regard to undesirable responses of the anesthetized patients (e.g.: pain, awakening) during surgical procedures.

Different anesthetic protocols for the premedication, induction and maintenance of general anesthesia using the TIVA have been applied in dogs. It is obvious that propofol is the drug of choice for TIVA and it is applied mostly in combination with an analgesic agent, such as fentanyl, which provides a sufficient degree of analgesia required for surgical interventions as reviewed by Smith et al. [4]. The combination of both these drugs is recommended for TIVA due to their quick metabolism and rapid elimination from the body [5]. Furthermore, it has been demonstrated that the metabolism of propofol can be inhibited by fentanyl [6], but little is known about the interactions between different drugs so far. For these reasons, an appropriate selection of agents used for premedication and anesthesia, with suitable pharmacokinetic and pharmacodynamic properties, as well as adequate dosage can significantly improve intraoperative cardiovascular stability, perioperative analgesia and the quality of recovery [7].

Therefore, this study was conducted to evaluate the impact of medetomidine, atropine and diazepam premedication or xylazine, atropine and diazepam premedication on total intravenous anesthesia induced and maintained with propofol/fentanyl on the cardio-respiratory function and hemodynamic changes in healthy dogs undergoing surgical procedures.

\section{MATERIAL AND METHODS}

\section{Animals}

Twenty-four dogs were randomly divided into two experimental groups with different premedication protocols (AMD-group: $\mathrm{n}=12$ - medetomidine (Cepetor, CP Pharma, Germany) + atropine (ATROPINE, Biotika, Slovak Republic) + diazepam (Apaurin, KRKA, Slovenia); XMD-group: $\mathrm{n}=12$ - xylazine (Rometar, Bioveta, Slovak Republic) + atropine + diazepam). Based on ASA Physical Status Classification System [8], all 
dogs were considered to be suitable for surgery (such as: castration, ovariohysterectomy, cranial cruciate ligament surgery, endodontic and orthodontic treatment). The study was approved by the local Ethics Committee. The owners were fully informed and agreed with the anesthetic protocol.

\section{Experimental design}

Food was withheld for 12 hours prior to anesthesia, but dogs had free access to water. Following the placement of the catheters into the $v$. saphena dextra for a propofol/ fentanyl constant rate infusion total intravenous anesthesia (P/F TIVA) and into the v. cephalica antebrachii dextra for blood sampling, premedication was performed using intravenous (i.v.) medetomidine (M) or i.v. xylazine (X) at doses of $0.02 \mathrm{mg} / \mathrm{kg}$ and $0.7 \mathrm{mg} / \mathrm{kg}$, respectively, in combination with atropine (A, dose $0.02 \mathrm{mg} / \mathrm{kg}$ i.v.) and diazepam (D, dose $0.5 \mathrm{mg} / \mathrm{kg}$ i.v.). After recording the sedation score $(5,10,15$ min.), i.v. propofol (Propofol, Fresenius Kabi, Germany; dose $2 \mathrm{mg} / \mathrm{kg}$ ) and fentanyl (Fentanyl TORREX, Chiesi Pharmaceuticals, Austria; dose $2 \mu \mathrm{g} / \mathrm{kg}$ ) were used for the induction of anesthesia. Intubation was performed and subsequently the dogs were placed in a left recumbent position. Immediately after positioning, an i.v. infusion of propofol/fentanyl mixture at doses of $0.2 \mathrm{mg} / \mathrm{kg}$ per min. and $0.2 \mu \mathrm{g} / \mathrm{kg}$ per min. was started and maintained throughout the P/F TIVA by an infusion system IPB 2050 (Polymed, CZ). Subsequently, the patient was prepared for the surgical procedure. Small boluses of propofol (1 mg/ $\mathrm{kg}$ i.v. $)$ or fentanyl $(1 \mu \mathrm{g} / \mathrm{kg}$ i.v. $)$ should have been applied when inadequate anesthesia was recorded (muscle movements in response to surgical stimulation). When the anesthesiologist found an excessive depth of anesthesia, based on the palpebral and corneal reflex, position of the eyeball and size of the pupils, the infusion rate was reduced to $0.1 \mathrm{mg}$ of propofol $/ \mathrm{kg}$ per min. and 0.1 $\mu \mathrm{g}$ of fentanyl $/ \mathrm{kg}$ per min. The occurrence of apnea for a period longer than 20-30 sec. was indicative for an intermittent positive pressure ventilation and discontinuation of the propofol and fentanyl infusion. These dogs were ventilated 1-1.5 min. until spontaneous ventilation was restored and RR increased up to 6 breaths per minute.

Preanesthetic sedation, induction and endotracheal intubation scales [9] were used to assess the sedation score during premedication at the 5 th, 10th and 15 th $\mathrm{min}$. $(-15$, $-10,-5$, respectively), and after induction and intubation, respectively. At the end of the P/F TIVA, all dogs laying in a lateral recumbency were placed in the recovery room. During the recovery, each dog was observed independently by an experienced anesthesiologist to examine four criteria as follows: time to extubation, time to head lift, time to sternal recumbency, and time to standing without assistance. In addition, the recovery period of each dog was evaluated until the decision on the final recovery score following anesthesia according to Jiménez [10] was confirmed.

\section{Sample and data collection and their analyses}

Before the premedication ( $\mathrm{C}$ - baseline values), and immediately at the beginning of the P/F TIVA (0), at 10 min. intervals for 2 hours $(10,20,30,40,50,60,70,80$, 
90, 100, 110, 120), and after the P/F TIVA at the time when the dogs were able to stand without assistance (POST), the heart rate (HR, heart beats per min.), respiratory rate $(\mathrm{RR}$, breaths per min.), systolic (SBP, $\mathrm{mmHg}$ ), diastolic (DBP, $\mathrm{mmHg}$ ) and mean (MBP, $\mathrm{mmHg}$ ) blood pressures were recorded on the left thoracic limb by a Patient Monitor-9000Vet (Hamburg, DE). The blood pressures were measured only during the $\mathrm{P} / \mathrm{F}$ TIVA, when the dogs were not able to resist the restraint. In addition, at $\mathrm{C}$, 0, 30, 60, 90, $120 \mathrm{~min}$, the blood was collected into heparinized capillary test tubes to determine the acid-base balance. Immediately after collection, the blood samples were analyzed by a blood acid-base analyzer ABL5 (Radiometer Copenhagen, DEN).

\section{Statistical analyses}

The results are presented as mean values \pm standard deviation. As comparing both groups, statistical analysis of the same indices in a row was done using the paired Student's t-test $\left(* \mathrm{P}<0.05, * * \mathrm{P}<0.01,{ }^{*} * * \mathrm{P}<0.001\right)$. Within the same group, except for SBP, MBP and DBP, all indices were compared to $\mathrm{C}$ using a one-way ANOVA with the Dunnet's post-test $\left({ }^{\mathrm{a}} \mathrm{P}<0.05,{ }^{\mathrm{b}} \mathrm{P}<0.01\right)$.

\section{RESULTS}

When comparing the experimental groups, AMD vs. XMD the following sedation scores (-15: $3.0 \pm 0.6$ vs $2.0 \pm 0.4 ;-10: 3.8 \pm 0.5$ vs $2.4 \pm 0.5 ;-5: 4.2 \pm 0.4$ vs. $3.1 \pm 0.3$ ), anesthetic induction scores $(1.1 \pm 0.3$ vs $1.2 \pm 0.4)$, and endotracheal intubation scores (1.0 \pm 0.0 vs. $1.3 \pm 0.5)$ were observed.

Changes of the hemodynamic indices are summarized in Table 1. In both groups, $\mathrm{pH}$ started to fall at $0\left(7.29 \pm 0.06^{\mathrm{b}}\right.$ vs. $\left.7.35 \pm 0.03^{\mathrm{a}},{ }^{* *} \mathrm{P}<0.01\right)$ and was significantly decreased until the end of the $\mathrm{P} / \mathrm{F}$ TIVA when compared to C. The AMD-group showed a more significant alteration of $\mathrm{pH}$ within the 1 st hour of the $\mathrm{P} / \mathrm{F}$ TIVA due to more observable depressant effects of medetomidine. (AMD/0: $7.29 \pm 0.06$, $\mathrm{AXD} / 0: 7.35 \pm 0.03, * * \mathrm{P}<0.01 ; \mathrm{AMD} / 30: 7.2 \pm 0.08, \mathrm{AXD} / 30: 7.27 \pm 0.03, * \mathrm{P}<0.05$; $\mathrm{AMD} / 60: 7.17 \pm 0.09, \mathrm{AXD} / 60: 7.2 \pm 0.03, * \mathrm{P}<0.05)$.

At 30 min., significantly increased $\mathrm{pCO}_{2}$ was found in the AMD-group $\left(8.03 \pm 1.53^{\mathrm{b}} \mathrm{vs}\right.$ $\left.6.63 \pm 0.74^{\mathrm{b}}, * * \mathrm{P}<0.01\right)$ and $\mathrm{pO}_{2}$ was significantly increased in the AMD-group from $90\left(9.68 \pm 2.67^{\mathrm{a}}\right.$ vs $\left.7.18 \pm 2.38^{\mathrm{b}}, * \mathrm{P}<0.05\right)$ to $120 \mathrm{~min} .(10.9 \pm 4.08$ vs $6.9 \pm 2.71, * * \mathrm{P}$ $<0.01)$. This can be explained by a reduction of the rate of propofol/fentanyl TIVA administration and oxygenation initiated due to an excessively deep anesthesia detected by an anesthesiologist, leading to an improvement in the ventilation and an increase in pO2. In both groups, $\mathrm{HCO}_{3}$ was relatively stable, but $\mathrm{SBC}$ and $\mathrm{BE}$ were found to be significantly decreased when compared to $\mathrm{C}$. There were no significant differences in these indices between the treatments. In both groups, the changes induced by the $\mathrm{P} / \mathrm{F}$ TIVA were counterbalanced at POST.

Changes in HR, RR, SBP, MBP and DBP are presented in Table 2. When comparing the groups, HR started to fall earlier (at 10) in the AMD-group (at 70 in the XMD- 


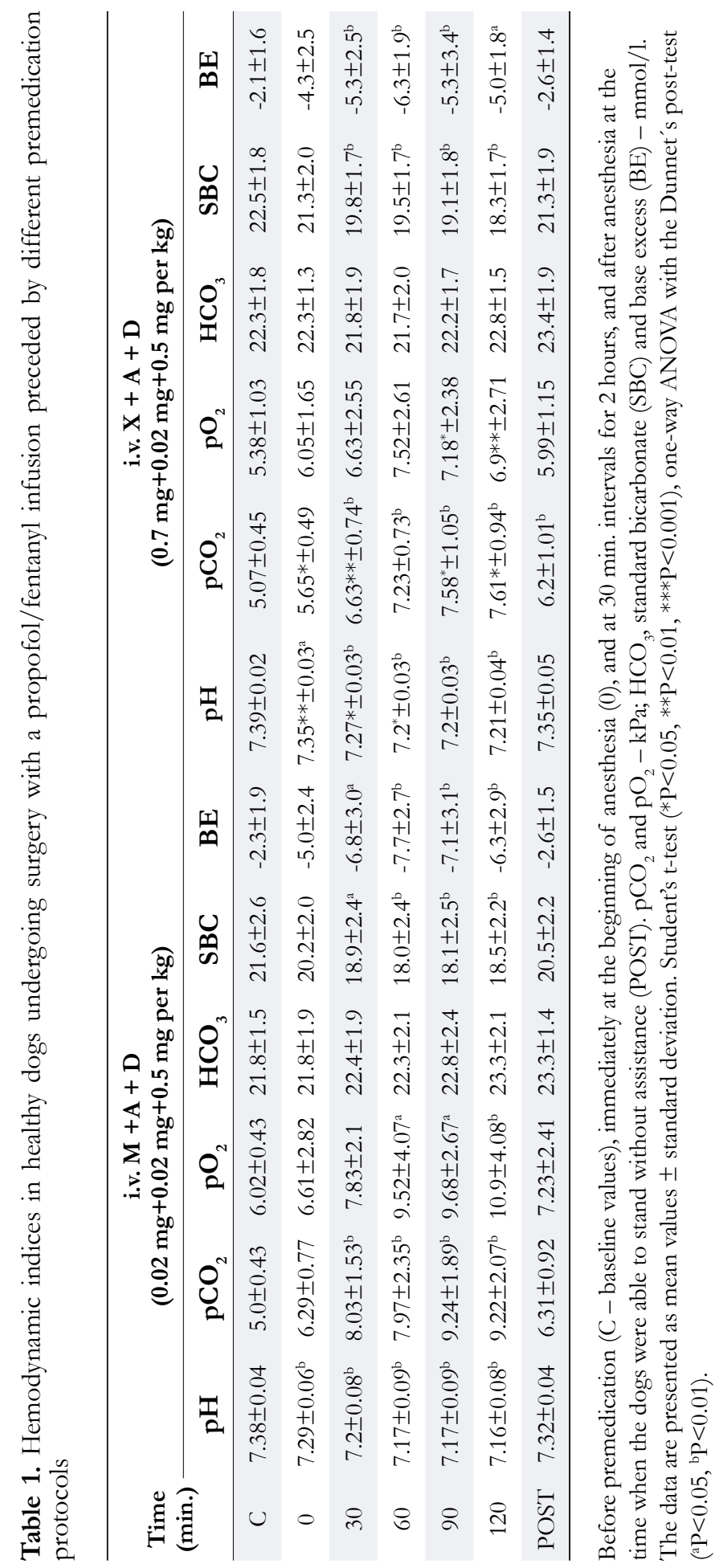




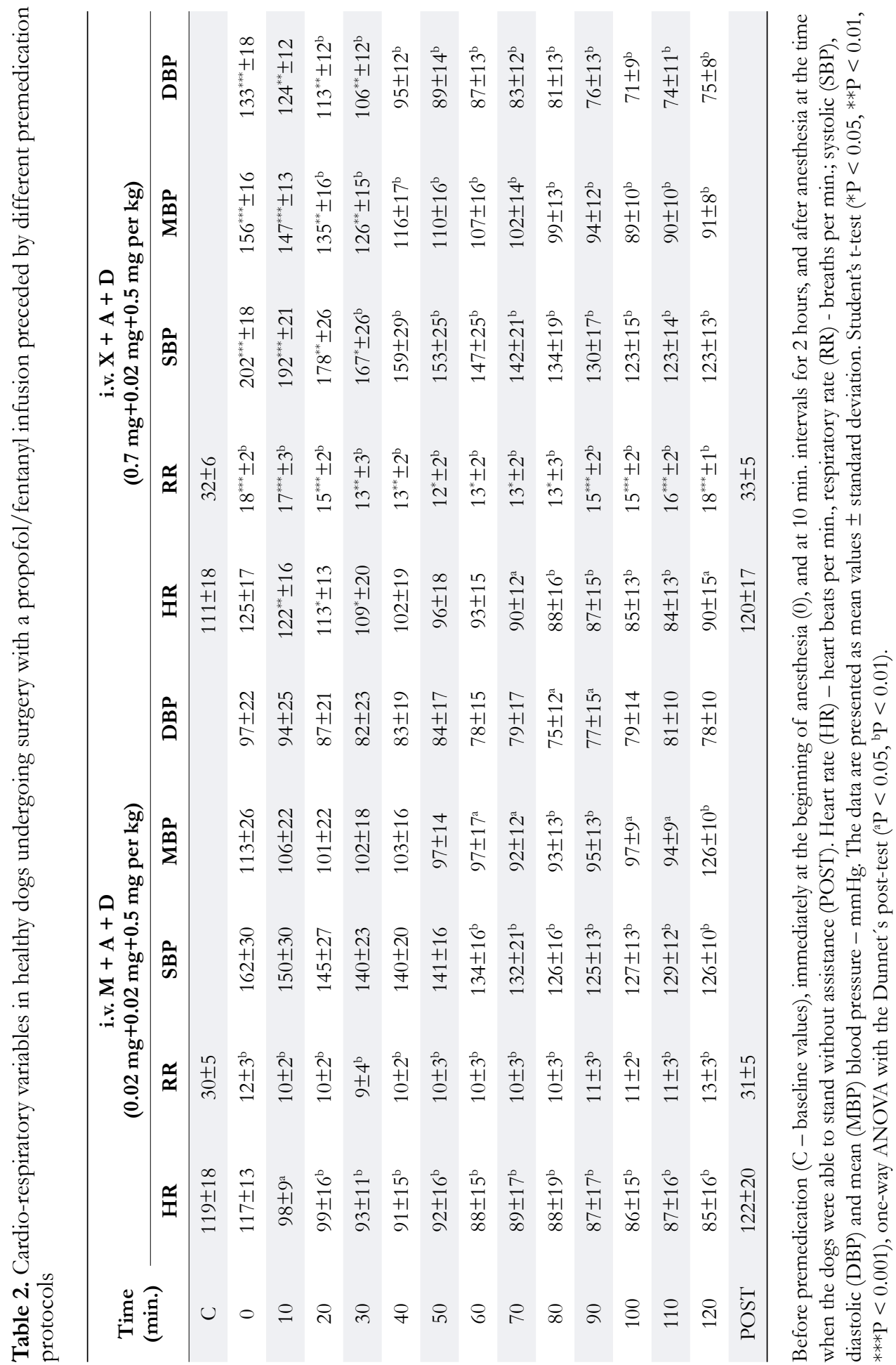


group), and RR decreased immediately at the beginning of the P/F TIVA in both groups. Moreover, at the beginning of the P/F TIVA, the value of BP was significantly lower in the AMD-group when compared with the AXD-group (SBP:AMD 162 \pm

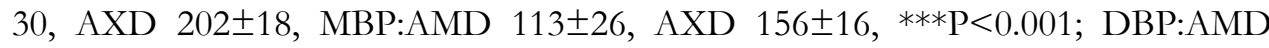
$97 \pm 22$, AXD 133 $\pm 18, * * * \mathrm{P}<0.001), \mathrm{pH}\left(7.29 \pm 0.06^{\mathrm{b}}\right.$ vs $\left.7.35 \pm 0.03^{\mathrm{a}}, * * \mathrm{P}<0.01\right)$. The initial hypertension was caused by increased $\mathrm{HR}$, respectively by premedication with atropine and vasoconstriction caused by alpha - 2 agonists. It is noticeable that within the 1st hour of the P/F TIVA, HR, RR SBP, MBP and DBP have a tendency to decrease more severely in the AMD-group, but then (except for RR) both groups leveled in regard to the cardio-respiratory parameters. Except for spontaneous blinking in response to surgical stimulation seen in both groups throughout the P/F TIVA, apnea was recorded in five dogs in the AMD-group. Changes in the acid-base balance during anesthesia were not significant compared to the dogs without apnea.

Statistical differences between the AXD-group and the AMD-group (Table 3) were recorded for the shorter time to extubation ( $9 \pm 3$ vs $13 \pm 5, * \mathrm{P}<0.05$ ), sternal recumbency $(29 \pm 11$ vs $39 \pm 11, * \mathrm{P}<0.05)$, head lift $(17 \pm 7$ vs $27 \pm 11, * \mathrm{P}<0.05)$ and

Table 3. Premedication, induction, intubation and recovery scores, and other criteria examined during recovery in healthy dogs undergoing surgery

\begin{tabular}{|c|c|c|c|}
\hline & $\begin{array}{l}\text { Time to administration of } \\
\text { propofol/fentanyl (min.) }\end{array}$ & $\begin{array}{c}\text { i.v. } M+A+D \\
(0.02 \mathrm{mg}+ \\
0.02 \mathrm{mg}+0.5 \mathrm{mg} \\
\text { per kg, resp. })\end{array}$ & $\begin{array}{c}\text { i.v. } X+A+D \\
(0.7 \mathrm{mg}+ \\
0.02 \mathrm{mg}+0.5 \mathrm{mg} \\
\text { per kg, resp.) }\end{array}$ \\
\hline \multirow{3}{*}{$\begin{array}{l}\text { Premedication } \\
\text { score }\end{array}$} & -15 & $3.0 \pm 0.6$ & $2.0 \pm 0.4$ \\
\hline & -10 & $1.8 \pm 0.5$ & $2.4 \pm 0.5$ \\
\hline & -5 & $4.2 \pm 0.4$ & $3.1 \pm 0.3$ \\
\hline \multicolumn{4}{|c|}{ Induction of TIVA with i.v. propofol and i.v. fentanyl } \\
\hline Induction score & Prior and during the intubation, resp. & $1.1 \pm 0.3$ & $1.2 \pm 0.4$ \\
\hline Intubation score & & $1.0 \pm 0.0$ & $1.3 \pm 0.5$ \\
\hline \multicolumn{4}{|c|}{ TIVA maintained with propofol/fentanyl for 2 hours } \\
\hline \multirow[t]{4}{*}{$\begin{array}{l}\text { Recovery from } \\
\text { anesthesia }\end{array}$} & $\begin{array}{l}\text { Time to } \\
\text { - extubation (min.) }\end{array}$ & $13 \pm 5$ & $9 \pm 3^{*}$ \\
\hline & - head lift (min.) & $27 \pm 11$ & $17 \pm 7^{*}$ \\
\hline & - sternal recumbency (min.) & $39 \pm 11$ & $29 \pm 11 *$ \\
\hline & - standing without assistance (min.) & $67 \pm 7$ & $56 \pm 13^{*}$ \\
\hline Recovery score & & $1.8 \pm 0.9$ & $1.9 \pm 1.0$ \\
\hline
\end{tabular}

The propofol/fentanyl infusion preceded with intravenous medetomidine (M), atropine (A) and diazepam (D) or intravenous xylazine $(\mathrm{X})$, atropine and diazepam as premedication. The data are presented as mean values \pm standard deviation. Student's t-test $(* \mathrm{P}<0.05)$. 
standing without assistance $(56 \pm 13$ vs $67 \pm 7, * \mathrm{P}<0.05)$ in the AXD-group. Neither whining nor vomiting was seen, but some side effects (drowsiness, ataxia) of the drugs used were found in both groups during the recovery. All dogs included in this study recovered from the $\mathrm{P} / \mathrm{F}$ TIVA without any pharmacological or critical care interventions.

\section{DISCUSSION}

It is well known that in dogs the administration of medetomidine is accompanied with cardiorespiratory depression $[11,12]$. The $\mathrm{PaO}_{2}$ and $\mathrm{PaCO}_{2}$ were significantly decreased in dogs treated with medetomidine within $30 \mathrm{~min}$. after its administration [13]. As published by Yamashita et al. [14], medetomidine as well as xylazine have the ability to induce cardiovascular depression. On the other hand, Ko et al. [11] found that atropine prevents medetomidine induced bradycardia for $50 \mathrm{~min}$. after its administration. Moreover, diazepam is a profound sedative and anticonvulsant which makes the organism feel less agitated and less tense. For these reasons, we can predict that sinus bradycardia (heart rate $<60$ beats per min.) was not observed throughout the P/F TIVA in both groups probably due to the administration of atropine in the premedication. Vomitus was observed in up to $60 \%$ of dogs within 5 min. after administration of medetomidine $(40 \mu \mathrm{g} / \mathrm{kg})$ or xylazine $(2.2 \mathrm{mg} / \mathrm{kg})$. The preanesthetic fasting, as well as the reduced doses of both these drugs in our study, can be the cause that nausea or vomitus were not seen in any of the observed dogs. In accordance with our results, the applied dose of medetomidine $(20 \mu \mathrm{g} / \mathrm{kg})$, in combination with atropine and diazepam, is able to induce a deep sedation in dogs [13]. On the other hand, the dose of xylazine $0.7 \mathrm{mg} / \mathrm{kg}$ in combination with atropine and diazepam had a lower sedative effect. All in all, even a moderate sedation achieved in the AXD-group at -5 inhibited the resistance of dogs to the preoperative procedures.

In human and canine patients a propofol/fentanyl infusion produces a rapid, pleasant and safe anesthesia with only a few untoward side effects with minor hemodynamic fluctuations and with a smooth and swift recovery [5, 15]. De Mulder et al. [16] found that the TIVA with propofol and fentanyl provided a stable cardiovascular function in vagotomized rabbits after sternotomy. Similarly, in racing dogs undergoing a surgical intervention, TIVA maintained with propofol and fentanyl, premedicated only with atropine, secures an anesthesia without bradycardia despite some undesirable reactions such as leg paddling and whining, seen during the recovery [17]. It has been shown that the application of propofol with fentanyl depresses the ventilation of lungs in humans [18]. On the other hand, Andreoni and Hughes reported stable cardiovascular functions in dogs undergoing surgical procedures throughout the propofol/fentanyl infusion and a smooth recovery from the anesthesia. A decreased HR was recorded from 10 to 30 min. of anesthesia but their dogs were premedicated with intramuscular acepromazine (up to $0.5 \mathrm{mg} / \mathrm{kg}$ ) and subcutaneous carprofene (4 mg/kg) administration. Dzikiti et al. [20] found that a propofol/fentanyl infusion 
for $90 \mathrm{~min}$. did not require assisted respiration, but recovery was not always smooth in goats. In our study, during the propofol/fentanyl infusion, the depression of the cardiovascular system in the AXD-group was delayed for 1 hour when compared with the AMD-group. Although, RR started to decrease immediately after the induction of TIVA in both groups, the initial values of RR, as nearly all the studied indices, were more preferable in regard to the general anesthesia in the AXD-group. This indicates that the protocol used for the premedication can significantly affect the values of cardio-pulmonary, hemodynamic and acid-base indices at the onset of anesthesia and thus may influence the intraoperative stability of patients, as well as the length of the recovery period. Contrary to our findings, Bajwa et al. [5] found that propofol/fentanyl infusion caused a mild excitation in human patients based on slightly increased RR and blood pressure, but a slight respiratory depression was seen during recovery. The most evident side effect of the medetomidine premedication followed with a propofol infusion was hypoxemia [21]. During the anesthesia, signs of slight hypoxia were seen in both groups based on acid-base analysis, but rapidly reversible apnea was recorded in five dogs only in the AMD-group.

It can be concluded that xylazine + atropine + diazepam premedication is apparently a better option for the premedication of healthy dogs undergoing prolonged surgical procedures using a propofol/fentanyl TIVA, in spite of the fact that lower sedation scores were attained, due to its less marked adverse cardio-respiratory and hemodynamic effects in comparison with medetomidine+atropine+diazepam premedication. Hypertension as an adverse effect of this combination could be minimized by using atropine due to its ability to cause bradycardia and subsequent hypotension. Furthermore, apnea was not recorded in the AXD-group, thus these dogs breathed spontaneously during the entire TIVA, also the time needed to stand without assistance was shorter in these dogs when compared to the AXD-group.

\section{Acknowledgements}

This research was supported by VEGA grant no. 1/0212/12 from the Ministry of Education, Science, Research and Sport of the Slovak Republic.

\section{REFERENCES}

1. Trbolová A: Anaesthesia. WSAVA, CEP, Beograd - Serbia and Montenegro, June 3, 2006, 1-29

2. Seliškar A, Rostaher A, Ostrouška M, Butinar J: Intra- and post-operative analgesic effects of carprofein in medetomidine-premedicated dogs undergoing ovariectomy, Acta Veterinaria (Beograd), 2005, 55 (5-6), 435-448.

3. Genter A, Capak H, Lipar M, Samardžija M, Harapin I, Bedrica L, Capak D: Antimicrobial prophylaxis in addition to premedication in gastrointestinal surgery, Acta VeterinariaBeograd 2014, 64 (1), 149-155. 
4. Smith I, White PF, Nathanson M, Gouldson R: Propofol. An update on its clinical use. Anesthesiology 1994, 81:1005-43.

5. Bajwa SJS, Bajwa SK, Kaur J: Comparison of two drug combinations in total intravenous anesthesia: Propofol-ketamine and propofol-fentanyl. Saudi J Anaesth 2010, 4:72-9.

6. Le Guellec C, Lacarelle B, Villard PH, Point H, Catalin J, Durand A: Glucuronidation of propofol in microsomal fractions from various tissues and species including humans: effect of different drugs. Anesth Analg 1995, 81:855-861.

7. Waelders T, Vermoere P, Polis I: Total intravenous anesthesia in dogs. Vlaams Diergen Tijds 2009, 78:160-169.

8. Bednarski R, Grimm K, Harvey R, Lukasik VM, Penn WS, Sargent B, Spelts K: AAHA anesthesia guidelines for dogs and cats. J Am Anim Hosp Assoc 2011, 47:377-85.

9. Maidden K, Adams VJ, Hill NAT, Leece EA: Alfaxalone induction dose following administration of medetomidine and butorphanol in the dog. Vet Anesth Analg 2010, 37:713.

10. Jiménez CP, Mathis A, Mora SS, Brodbelt D, Alibhai H: Evaluation of the quality of the recovery after administration of propofol or alfaxalone for induction of anaesthesia in dogs anaesthetized for magnetic resonance imaging. Vet Anaesth Analg 2012, 39:151-9.

11. Ko JC, Fox SM, Mandsager RE: Comparison of sedative and cardiorespiratory effects of medetomidine and medetomidine-butorphanol combination in dogs. J Am Vet Med Assoc 2000, 216:1578-1583.

12. Kuo WC, Keegan RD: Comparative cardiovascular, analgesic, and sedative effects of medetomidine, medetomidine-hydromorphone, and medetomidine-butorphanol in dogs. Am J Vet Res 2004, 65:931-937.

13. Raekallio MR, Räihä MP, Alanen MH, Sarén NM, Tuovio TA: Effects of medetomidine, L-methadone, and their combination on arterial blood gases in dogs. Vet Anaesth Analg 2009, 36:158-61.

14. Yamashita K, Tsubakishita S, Futaok S, Ueda I, Hamaguchi H, Seno T, Katoh S, Izumisawa Y, Kotani T, Muir WW: Cardiovascular effects of medetomidine, detomidine and xylazine in horses. J Vet Med Sci 2000, 62:1025-32.

15. Kürüm B, Pekcan Z, Kalender H, Kumandaş A, Can Mutan O, Elma E: Comparison of propofol-remifentanil and propofol-fentanyl anesthesia during ovariohysterectomy in dogs, Kafras Univ Vet Fak Derg 2013, 19: A33-A40

16. De Mulder PA, Van Kerckhoven RJ, Adriaensen HF, Gillebert TC, De Hert SG: Continuous total intravenous anesthesia, using propofol and fentanyl in an open-thorax rabbit model: evaluation of cardiac contractile function and biochemical assessment. Lab Anim Sci 1997, 47:367-75.

17. Hughes JML, Nolan AM: Total intravenous anesthesia in Greyhounds: Pharmacokinetics of propofol and fentanyl - A preliminary study. Vet Surg 1999, 28:513-524.

18. Tanaka S, Tsuchida H, Sonoda H, Namiki A: Respiratory and cardiovascular effects of fentanyl during propofol-induced sedation under spinal anesthesia. J Anesth 1998, 12:171174.

19. Andreoni V, Hughes JML: Propofol and fentanyl infusions in dogs of various breeds undergoing surgery. Vet Anaesth Analg 2009, 36:523-531. 
20. Dzikiti BT, Stegmann FG, Dzikiti LN, Hellebrekers LJ: Total intravenous anaesthesia (TIVA) with propofol-fentanyl and propofol-midazolam combinations in spontaneouslybreathing goats. Vet Anaesth Analg 2010, 37:519-25.

21. Cullen LK, Reynoldson JA: Xylazine or medetomidine premedication before propofol anaesthesia. Vet Rec 1993, 132:378-383.

\section{KARDIORESPIRATORNI I HEMODINAMIČKI EFEKTI MEDETOMIDINA ILI KSILAZINA SA ATROPIN I DIAZEPAM PREMEDIKACIJOM PRILIKOM INDUKOVANJA TOTALNE INTRAVENSKE ANESTEZIJE SA PROPOFOL/FENTANIL-OM KOD PASA TOKOM HIRURŠKIH INTERVENCIJA}

LIPTÁK Tomáš, CAPÍK Igor, LEDECKÝ Valent, NAGY Oskar, KURICOVÁ Mária, TÓTHOVÁ Csilla, MAĎARI Aladár, FARBÁKOVÁ Jana, PETROVIČ Vladimír, HORÑ́́K Slavomír

Obavljeno je upoređivanje efekata različitih protokola premedikacije koji su prethodili propofol/fentanil TIVA na kardio-respiratorne i hemodinamičke promene kod 24 psa koji su podeljeni u dve grupe (AMD-grupa: medetomidin, atropin i diazepam; AXD-grupa: xylazin, atropin i diazepam). Tokom ogleda, praćene su promenljive kardio-respiratorne vrednosti, acido-bazne vrednosti, kvalitet sedacije, indukcija sedacije, intubacija i stepen oporavka od anestezije.

Značajne promene su uočene u odnosu na pO2 koje su bile povećane u AMD-grupi od $90(* \mathrm{P}<0.05)$ do 120 minuta $(* * \mathrm{P}<0.01)$ anestezije. Ovo može da se objasni smanjenjem brzine davanja propofol/fentanil TIVA i oksigenacijom koja je izazvana naročito dubokom anestezijom koja je uočena od strane anesteziologa, što je vodilo pojačanoj ventilaciji i povećanim vrednostima $\mathrm{pO} 2$. Zahvaljujući slabijim depresivnim efektima ksilazina, u AXD grupi, nivoi pCO2 $(* \mathrm{P}<0.05)$ su dostizali željene vrednosti tokom prvih 30 minuta, a $\mathrm{pH}(* * \mathrm{P}<0.01)$ vrednosti su bile značajno poboljšane $\mathrm{u}$ prvih 60 minuta. U prvih 30 minuta anestezije, uočene su značajne razlike u radu srca (puls) između grupa pri čemu su vrednosti BP (hipertenzija) bile značajno veće u AXD grupi $\left(10 \mathrm{~min} .{ }^{* * *} \mathrm{P}<0.001,30 \mathrm{~min} .{ }^{* *} \mathrm{P}<0.01\right)$. Ovo ukazuje na mogućnost aplikacije atropina samo u slučaju postojanja tendencije razvoja bradikardije koja bi prethodila hipotenziji.

$\mathrm{Na}$ osnovu rezultata može da se zaključi da je ksilazin bolja opcija za premedikaciju tokom propofol/fentanil TIVA anestezije kod pasa tokom produžene hirurške intervencije, uprkos činjenici da su ustanovljeni niži skorovi sedacije. Ustanovljeni su manje značajni neželjeni kardio-respiratorni i hemodinamički efekti ksilazina, kao i kraće vreme buđenja u poređenju sa medetomidinom. 